\title{
DIAGNOSIS OF PREGNANCY AND EXPERIMENTAL EXTENSION OF GESTATION IN THE PIPISTRELLE BAT, PIPISTRELLUS PIPISTRELLUS
}

\author{
P. A. RAGEY \\ Wellcome Institute of Comparative Physiology, Zoological Society of London, \\ Regent's Park, London \\ (Received 8th Fuly 1968)
}

\begin{abstract}
Summary. The reliability of palpation, weighing, radiography and the state of the nipples is discussed in relation to the determination of pregnancy in the pipistrelle.

In two series of pregnant pipistrelles, the mean length of gestation has been extended by the induction of torpor at different stages during pregnancy and this extension is in good agreement with the period of torpor. Pregnancy is thought to be extended in response to adverse conditions in the natural environment, and the present concept of a standard gestation period for these heterothermic animals is therefore questioned.
\end{abstract}

\section{INTRODUCTION}

In animals which are not subject to a delay of either fertilization or implantation, the interval between copulation and parturition provides some information about the length of gestation, since the time of copulation and ovulation are often closely and constantly related. Copulation in vespertilionid bats of temperate regions is generally thought to take place in the autumn and to precede ovulation by a variable length of time. This interval is at least 5 months in Eptesicus fuscus and Myotis lucifugus (Wimsatt, 1944a). In these examples, the delay of fertilization includes the period of hibernation. Copulation of males with torpid females has been reported to occur at random during the winter, as for example in $M$. nattereri and $M$. daubentoni (Gilbert \& Stebbings, 1958; Stebbings, personal communication), while species such as Plecotus auritus (Moffat, 1922; Stebbings, 1966) and Pipistrellus pipistrellus (Courrier, 1922; Aubert, 1963) are reported to copulate in autumn and spring. Strelkov (1962), studying $M$. dasycneme, $M$. mystacinus, $M$. daubentoni and $P$. auritus near the northern border of their distribution, has shown that an increasing proportion of females are inseminated during the period of hibernation. Ovulation in all these species occurs after emergence from hibernation in spring and would appear to depend on a particular set of environmental conditions affecting the metabolic processes in general and the pituitary gland in particular. It was suggested by Wimsatt (1944b) that ovulation may be 
associated with the flight from the winter hibernaculum to the summer nursery colony.

Information about the length of gestation may be obtained indirectly by histological examination of a large series of animals removed from breeding colonies. Thus, Deanesly \& Warwick (1939) after examination of a continuous series of pregnancy stages from Scottish colonies of pipistrelles estimated that pregnancy lasts for approximately 44 days. Ovulation was thought to occur in May and the births, 95\% of which are singletons, in June and July. In France, however, Courrier (1922) reported for the same species that ovulation occurred in March and April and births in July and August. This indicates a longer period of gestation on the Continent. Alternatively, ovulation may be induced by premature arousal of animals from hibernation alone (Guthrie \& Jeffers, 1938; Sluiter \& Bels, 1951), or by the injection of such animals with exogenous gonadotrophins (Wimsatt, 1960), and the subsequent pregnancies allowed to come to term. Experiments to investigate this are in progress.

The temperature and metabolic rates of several species of bats have been shown to be influenced by environmental conditions (Hock, 1951). During hibernation, they are frequently in deep torpor from which they may awake occasionally to change their position, fly and feed (Ransome, 1968). During the summer they are often in a state of 'day-sleep-lethargy' (Tagesschlaflethargie, Eisentraut, 1937), the degree of which depends on the environmental conditions. Torpor may be induced at any time during the year by subjecting bats to a temperature of 5 to $15^{\circ} \mathrm{C}$, and animals can be maintained for several weeks in this condition. Previous observations (Racey, unpublished) of bats caught from hibernation and kept in this way had shown that even those which were successfully trained to feed before the induction of torpor never aroused from their torpid state in order to eat, although food was continuously available to them.

Eisentraut (1937) was the first to demonstrate the effect of changes of environmental temperature on the rates of foetal development in the bat. Pregnant $M$. myotis which he kept singly in rooms at different temperatures were found to contain foetuses of correspondingly different size. The present work investigates the effect of induced torpor on the length of gestation in the pipistrelle. During the course of these investigations, however, difficulty was experienced in the determination of pregnancy and hence the relative value of various methods of pregnancy detection were also examined.

\section{METHODS}

Pipistrelles were caught in mist nets as they emerged from their roosts in the roof of a stable at Britford in Wiltshire on 28th May 1967, and the side of a wooden house at Braintree in Essex on 9th June 1967. At Britford, fourteen bats were captured, representing about a third of those emerging. At Braintree, however, thirty-two were captured and very few escaped. All the animals from both roosts were females, providing further evidence for the segregation of the sexes and the formation of nursery colonies at this time of year (Deanesly \& Warwick, 1939). 
After capture the bats were transported to the laboratory, weighed and examined. They were caged in small wooden boxes $(12 \times 5 \times 4$ in.) lined with nylon net (Tygan, Fothergill and Harvey) which enabled them to climb and hang with ease. Every box had a sliding perspex front drilled with $\frac{3}{16}$ in. holes for ventilation. The animals were trained to feed on mealworms (larvae of Tenebrio molitor): in the first place, the viscera of decapitated mealworms were applied with forceps to the lips of bats held in the hand. After these were taken, the bats were next encouraged to chew the chitinous exoskeletons, and then to take intact mealworms from a dish placed in the cage. The duration of this training, upon which the success of using insectivorous bats as laboratory animals depends, is very variable. Some pipistrelles learn after the first feed; others require many training sessions before they will eat mealworms unaided.

Each bat was numbered in the wing membrane using a tattooing forceps. This method is of short-term use, as the small holes which outline the numbers tend to become obliterated in a few days as they heal. They can, however, be reopened with a mounted needle; if a scar then forms it is often unpigmented and the number can be recognized for several weeks. There was no incidence of infection in the wing membrane following this procedure, although it is obviously not as suitable as the use of numbered forearm rings. These were not, however, available at the time.

Four methods were then used to detect pregnancy: analysis of body weight, palpation, radiography and examination of nipples with a dissecting microscope.

Bats confined in a small cardboard box were weighed on an Oertling lever balance. The criterion used in palpation was the degree of resistance to digital pressure applied to the abdominal wall; a conceptus could not be felt at the stages of pregnancy under consideration. Bats with abdominal walls that did not yield to pressure were classified as pregnant while those with more elastic abdominal walls were classified as non-pregnant. Previous experience of palpation followed by dissection had shown that very heavy deposition of splanchnic fat (which sometimes occurs in captive bats having an unlimited supply of food) could also increase resistance to external pressure. The conclusions from palpation were, therefore, checked by radiography. A $1000 \mathrm{~mA} / 150 \mathrm{kVp}$ $\mathrm{X}$-ray unit was used. The bats were placed in turn in a perspex tube with breathing holes in the sides. If subjected to a sudden noise immediately before exposure they 'froze', and a setting of $42 \mathrm{kVp}$ and 250 to $300 \mathrm{~mA}$ was successful at a focal film distance of $40 \mathrm{in}$. Fine grain industrial X-ray film was used (Ilford Industrial ' $\mathrm{F}$ ') and developed for $8 \mathrm{~min}$ at $20^{\circ} \mathrm{G}$ in Phenisol X-ray developer.

Temperatures of the animal room and the refrigerator were determined by means of a bimetallic strip pen recorder (thermograph) and mercury in glass maximum-minimum thermometer respectively.

\section{RESULTS}

\section{Observations}

THE BRITFORD COLONY

The average weight of the bats $36 \mathrm{hr}$ after capture on 28th May and before 
feeding was $4.72 \mathrm{~g}$ (fourteen animals: range 4.54 to $4.95 \mathrm{~g}$ ). The average weight of those later found to be pregnant was again $4.72 \mathrm{~g}$ and the two animals found later not to be pregnant weighed 4.80 and $4.55 \mathrm{~g}$. There is insufficient published information on the weights of pregnant pipistrelles to allow useful comparison of the present data.

None of the animals was palpably pregnant 23 days before the first bat gave birth and previous experience had shown that only after a foetus was detectable by abdominal palpation, could pregnancy be confirmed by means of X-rays.

Examination of the mammary area revealed that in none of the fourteen animals was there any development of mammary tissue, but there were considerable differences in the morphology of the nipples from which it was possible to deduce the reproductive condition of the bats as follows:

Type 1. Four bats had large flaccid nipples with emergent hair which was short, light brown in colour and wavy. These nipples had obviously been suckled and the animals were considered to be parous and therefore pregnant. Stebbings (personal communication) considers that some parous bats appear to miss a year's pregnancy, but this is assumed to be exceptional.

TABLE 1

BRITFORD BATS COLLEGTED 28TH MAY 1967

\begin{tabular}{|c|c|c|c|}
\hline Bat no. & Body wt $(g)$ & Condition of nipples & Remarks \\
\hline $\begin{array}{l}1 \\
2 \\
3 \\
4\end{array}$ & $\begin{array}{l}4 \cdot 76 \\
4 \cdot 95 \\
4 \cdot 85 \\
4 \cdot 77\end{array}$ & $\begin{array}{l}\text { Large and flaccid } \\
\text { with short, wavy } \\
\text { emergent hair }\end{array}$ & $\begin{array}{l}\text { Gave birth 22nd June } 1967 \\
\text { Gave birth 6th July } 1967 \\
\text { Gave birth 6th July } 1967 \\
\text { Killed: pregnant }\end{array}$ \\
\hline $\begin{array}{r}5 \\
6 \\
7 \\
8 \\
9 \\
10 \\
11 \\
12\end{array}$ & $\begin{array}{l}4 \cdot 62 \\
4 \cdot 66 \\
4 \cdot 52 \\
4 \cdot 89 \\
4 \cdot 75 \\
4 \cdot 55 \\
4 \cdot 55 \\
4 \cdot 88\end{array}$ & $\begin{array}{l}\text { Smaller but turgid } \\
\text { with emergent } \\
\text { body hair }\end{array}$ & $\begin{array}{l}\text { Escaped } \\
\text { Gave birth 25th June } 1967 \\
\text { Gave birth 11th July } 1967 \\
\text { Gave birth 22nd June } 1967 \\
\text { Gave birth 7th July } 1967 \\
\text { Killed: pregnant } \\
\text { Did not give birth } \\
\text { Escaped }\end{array}$ \\
\hline $\begin{array}{l}13 \\
14\end{array}$ & $\begin{array}{l}4.80 \\
4.54\end{array}$ & Rudimentary & $\begin{array}{l}\text { Killed: not pregnant } \\
\text { Killed: pregnant }\end{array}$ \\
\hline
\end{tabular}

Type 2. Eight bats had smaller but turgid nipples giving rise to body hair. Although these nipples did not appear to have been suckled, their turgidity indicated that they were developing. These bats were therefore considered to be nulliparous, but probably primigravid.

Type 3. Two bats had rudimentary nipples consisting of tiny protuberances giving rise to body hair. These were considered to be immature animals.

These deductions were checked by killing one each from groups (1) and (2) and both animals in group (3). All were found to be pregnant with the exception of one of the animals of Type 3 . Thus the presence of rudimentary nipples is no indication that an animal is either immature or not pregnant.

\section{Experiment 1}

The remaining ten animals were then trained to feed on mealworms and on 
6 th June, when their weights had increased sufficiently to confirm the success of training, they were divided into two groups. One group of five was placed in an unheated, poorly lit room on the roof, routinely used for housing bats. The temperature of this room during the experiment was 18 to $26^{\circ} \mathrm{C}$ and approximated to the conditions of the natural environment. The bats were examined daily with minimal disturbance for signs of parturition.

The second group of five was placed in a wooden cage in a refrigerator maintained at 11 to $14^{\circ} \mathrm{C}$ to induce torpor. Water was provided for the maintenance of humidity, but no food was given. The bats were inspected twice daily; at no inspection was any movement seen, and the animals were, therefore, considered to have been maintained in a state of continuous torpor. After 13 days they were removed and placed in the same conditions as the control group, where they resumed feeding and normal activity. Bats from these groups gave birth according to Table 2 .

TABLE 2

DATES OF BIRTH AND SEX OF YOUNG IN CONTROL AND EXPERIMENTAL GROUPS (EXPERIMENT 1)

\begin{tabular}{|c|c|c|c|}
\hline & Batno. & $\begin{array}{c}\text { Date of birth of young } \\
(1967)\end{array}$ & Sex of young \\
\hline Control group (18 to $26^{\circ} \mathrm{C}$ ) & $\begin{array}{l}8 \\
1 \\
6\end{array}$ & $\begin{array}{l}\text { 22nd June } \\
\text { 22nd June } \\
\text { 25th June }\end{array}$ & $\begin{array}{l}q \\
+ \\
+ \\
0\end{array}$ \\
\hline Experimental group $\left(11\right.$ to $\left.14^{\circ} \mathrm{C}\right)$ & $\begin{array}{l}2 \\
3 \\
9 \\
7\end{array}$ & $\begin{array}{l}\text { 6th July } \\
\text { 6th July } \\
\text { 7th July } \\
11 \text { th July }\end{array}$ & $\begin{array}{l}q \\
0 \\
q \\
q \\
q\end{array}$ \\
\hline
\end{tabular}

The difference between the mean date of birth of the group which had been maintained in a refrigerator for 13 days and that of the control group was $14 \frac{1}{2}$ days, and is significant at the $0.1 \%$ testing level.

\section{Observations}

THE BRAINTREE COLONY

The weight of the thirty-two bats, $17 \mathrm{hr}$ after capture on 9th June and before feeding, ranged from 3.27 to $6.01 \mathrm{~g}$ (average $4.96 \mathrm{~g}$ ). The average weight of the twenty-seven animals later diagnosed as pregnant was $5.11 \mathrm{~g}$ (range 4.08 to $6.01 \mathrm{~g}$ ), and that of five animals later diagnosed as not pregnant was $4.13 \mathrm{~g}$ (range 3.72 to $4.27 \mathrm{~g}$ ). Only one pregnant animal, with rudimentary nipples and weighing $4.08 \mathrm{~g}$, fell within the weight range of the non-pregnant group.

As the state of the nipples promised to be a useful criterion of pregnancy, particular attention was then paid to the examination of their morphology. Again no development of mammary tissue was noticeable, but the same three nipple types could be readily distinguished in different proportions from those in the Britford bats. 
Type 1. Twenty-seven bats had large flaccid nipples with short light brown and wavy emergent hair. In six of these the skin of the nipple was desquamating. In the remaining twenty-one the tip of the nipple was turgid, and the whole nipple was surrounded by a ring of light hair. The nipples of all these animals had obviously been suckled, and the animals were, therefore, considered to be parous and probably pregnant.

Type 2. One bat had small turgid nipples with emergent body hair and was considered to be primigravid.

Type 3 . Four bats had tiny nipple rudiments surrounded by a ring of lighter pigmented skin and giving rise to body hair. These were considered to be immature.

TABLE 3

BRAINTREE BATS GOLLEGTED 9TH JUNE 1967

\begin{tabular}{|c|c|c|c|c|}
\hline Bat no. & Body $w t(g)$ & $\begin{array}{c}\text { Condition of nipples } \\
\text { indicating animal is } \\
\text { pregnant }(P) \text { or } \\
\text { non-pregnant }(\mathcal{N} P)\end{array}$ & $\begin{array}{c}\text { Palpation } \\
\text { indicating animal is } \\
\text { pregnant }(P) \text { or } \\
\text { non-pregnant }(\mathcal{N} P)\end{array}$ & $\begin{array}{c}\text { Radiographic } \\
\text { indication } \\
\text { of } \\
\text { pregnancy }\end{array}$ \\
\hline $\begin{array}{l}15 \\
16 \\
17 \\
18 \\
19 \\
20 \\
21 \\
22 \\
23 \\
24 \\
25 \\
26 \\
27 \\
28 \\
30 \\
31 \\
32 \\
33 \\
34 \\
35 \\
36 \\
37 \\
38 \\
39 \\
40 \\
41 \\
42 \\
43 \\
44 \\
45 \\
46 \\
47\end{array}$ & $\begin{array}{l}5 \cdot 30 \\
4 \cdot 94 \\
4 \cdot 84 \\
5 \cdot 33 \\
5 \cdot 02 \\
5 \cdot 18 \\
4 \cdot 66 \\
5 \cdot 49 \\
5 \cdot 74 \\
5 \cdot 04 \\
5 \cdot 30 \\
5 \cdot 36 \\
5 \cdot 60 \\
5 \cdot 27 \\
4 \cdot 80 \\
5 \cdot 26 \\
5 \cdot 03 \\
5 \cdot 67 \\
6 \cdot 01 \\
4 \cdot 78 \\
4 \cdot 55 \\
4 \cdot 92 \\
5 \cdot 24 \\
4 \cdot 48 \\
4 \cdot 87 \\
5 \cdot 28 \\
4 \cdot 27 \\
4 \cdot 25 \\
3 \cdot 72 \\
4 \cdot 10 \\
4 \cdot 08 \\
4 \cdot 25\end{array}$ & $\begin{array}{l}P \\
P \\
P \\
P \\
P \\
P \\
P \\
P \\
P \\
P \\
P \\
P \\
P \\
P \\
P \\
P \\
P \\
P \\
P \\
P \\
P \\
P \\
P \\
P \\
P \\
P \\
P \\
P \\
N P \\
N P \\
N P \\
N P\end{array}$ & $\begin{array}{l}P \\
P \\
P \\
P \\
P \\
P \\
P \\
P \\
P \\
P \\
P \\
P \\
P \\
P \\
P \\
P \\
P \\
P \\
P \\
P \\
P \\
P \\
P \\
P \\
P \\
P \\
N P \\
N P \\
N P \\
N P \\
P \\
N P\end{array}$ & $\begin{array}{l}\text { Definite } \\
\text { Probable } \\
\text { Probable } \\
\text { Definite } \\
\text { Probable } \\
\text { Definite } \\
\text { Probable } \\
\text { Definite } \\
\text { Probable } \\
\text { Probable } \\
\text { Probable } \\
\text { Definite } \\
\text { Definite } \\
\text { Definite } \\
\text { Definite } \\
\text { Probable } \\
\text { Probable } \\
\text { Definite } \\
\text { Definite } \\
\text { Definite } \\
\text { Definite } \\
\text { Probable } \\
\text { Definite } \\
\text { Definite } \\
\text { Definite } \\
\text { Definite } \\
\text { Non-pregnant } \\
\text { Just possible } \\
\text { Just possible } \\
\text { Non-pregnant } \\
\text { Probable } \\
\text { Just possible }\end{array}$ \\
\hline
\end{tabular}

Of the twenty-eight animals which were classed as pregnant from the state of nipple development, only two (42 and 45) were later found non-pregnant by palpation and X-ray. Conversely, only one of four bats classified as nonpregnant from the state of the nipples was later found to be pregnant.

Conclusions from examination of the X-ray plates concerning the state of pregnancy of the animals fell into one of four categories: 
(a) definite: foetal parts obviously visible;

(b) probable: foetal parts (usually, it was thought, skull bone) often overlying the spine of the mother and consequently more difficult to distinguish;

(c) possible: foetal parts not seen with certainty, but suspected; abdomen swollen.

(d) non-pregnant: no indication of foetal parts; abdomen not swollen.

It can be seen from Table 3 that there is an absolute correlation between a positive diagnosis of pregnancy from palpation and a diagnosis from X-ray as definitely or probably pregnant, and likewise with a negative diagnosis from palpation and a diagnosis from $\mathrm{X}$-rays as just possibly pregnant or nonpregnant. All bats diagnosed as pregnant subsequently either gave birth or aborted whereas none of those diagnosed as non-pregnant did so. At this stage of pregnancy (14 days before the first bat gave birth), therefore, palpation gave the most convenient and accurate diagnosis of pregnancy.

\section{Experiment 2}

The disturbance and extensive handling of the bats at this later stage of pregnancy involved in the detection of pregnancy and training to feed caused eight animals to abort or die. On 16 th June, nineteen pregnant bats which had

\section{TABLE 4}

DATES OF BIRTH AND SEX OF YOUNG IN GONTROL AND EXPERIMENTAL GROUPS: (EXPERIMENT 2)

\begin{tabular}{|c|c|c|c|}
\hline & Bat no. & $\begin{array}{c}\text { Date of birth of young } \\
(1967)\end{array}$ & Sex of young \\
\hline Control group $\left(18\right.$ to $\left.26^{\circ} \mathrm{C}\right)$ & $\begin{array}{l}31 \\
41 \\
35 \\
23\end{array}$ & $\begin{array}{l}\text { 25th June } \\
\text { 26th June } \\
\text { 26th June } \\
\text { 2nd July }\end{array}$ & $\begin{array}{l}0 \\
0 \\
o+ \\
0 \\
0 \\
0\end{array}$ \\
\hline Experimental group $\left(11\right.$ to $14^{\circ} \mathrm{C}$ ) & $\begin{array}{l}32 \\
16 \\
25\end{array}$ & $\begin{array}{l}\text { 7th July } \\
9 \text { th July } \\
\text { 10th July }\end{array}$ & $\begin{array}{l}0 \\
0 \\
0 \\
0\end{array}$ \\
\hline
\end{tabular}

been successfully trained to feed and whose weights had therefore increased were divided into two groups to test the effect of lowered environmental temperature at a later stage of pregnancy (cf. Exp. 1). A control group of ten animals was maintained at a temperature of 18 to $26^{\circ} \mathrm{C}$ and examined daily for signs of parturition. Of these, however, all but four aborted or died. The remainder (nine) were caged at a temperature of 11 to $14^{\circ} \mathrm{C}$; water was provided for the maintenance of humidity, but no food was given. They were inspected twice daily, as before, and, as no movement was seen, a continuous state of torpor was considered to have been maintained. Twelve days later the bats were returned to the animal room. All but three aborted or died: as both groups were equally affected the damage is attributed to the extensive handling necessitated by pregnancy diagnosis and training to feed before the experiment was begun. 
The dates of parturition of the surviving Braintree bats are given in Table 4 . The difference (11 $\frac{1}{2}$ days) between the mean date of birth in the two groups is significant at the $1 \%$ testing level.

In both experiments, mothers reared their young well and the growth rates of the young from control and experimental groups did not differ significantly (Kleiman, 1969).

\section{DISCUSSION}

Of the methods that may be used to detect pregnancy in bats, palpation would seem to be the most reliable. This method has shown that embryos reach a palpable size between 23 and 14 days before birth. Measurable increase in maternal body weight also occurs within this period and, in the pipistrelle, the weight of the neonate is about $20 \%$ of that of the mother (Kleiman, 1969).

Parous animals, as judged by large nipples, were pregnant, with two exceptions (Nos. 42 and 45, from Braintree). These may have been pregnant and resorbed their embryos, or missed a year's pregnancy (Stebbings, personal communication). If the latter is the case, it is interesting in view of the low reproductive rate in this species of one young per mother per annum. Pregnant animals with small turgid nipples were considered to be primigravid, but there is no indication as to their age. Sluiter \& Bouman (1951) and Sluiter (1954) concluded that females of $M$. myotis and $M$. emarginatus became sexually mature in their 2 nd year. They agreed that during the winter small nipples were the most convenient external characteristic distinguishing nulliparous 1st and 2nd year females from older parous animals. Primigravid animals represented $57 \%$ of those caught at Britford, but only $3 \%$ of those caught at Braintree. This is difficult to explain, especially since so few animals of the Braintree colony escaped capture. Such a marked discrepancy between the proportion of primigravid animals in the two colonies casts doubts on the distinction made between the types of nipples in the Braintree colony and, in particular, on the division of the animals of Type I into six with large flaccid nipples alone, and twenty-one with large flaccid nipples each surmounted by a turgid tip. If the latter were considered to be primigravid then the total percentage of these animals in the Braintree group could be reassessed at $68 \%$. In doing this, however, animals possessing nipples which show the characteristics of previous suckling (large and flaccid with short fair and wavy emergent hair) must be classified as primigravid. This is obviously unacceptable.

Both the Britford and Braintree bats included a single pregnant female with rudimentary nipples. This is indicative of some difference between the primigravid animals with small turgid nipples and those with rudimentary nipples. The latter may be earlier in pregnancy or pregnant in their first spring, whereas the former may be breeding for the first time a year later, in their second spring. Until nipple movement is closely observed in bats of known age and reproductive history, the differences in nipple morphology described above cannot be conclusively explained.

The present experimental work on the pipistrelle, undertaken primarily to investigate the effect of lowered environmental temperature on pregnancy, has shown that pregnancy may be extended if the animals are subjected to a 
period of torpor. From the close agreement of the mean length of this extension with the period of induced torpor it would appear that development of the embryo slows drastically or stops altogether while the mother is torpid. Pregnant bats in their roosts spend varying amounts of time in this state depending on the ambient temperature, as demonstrated by Kolb (1950) for a colony of Rhinolophus hipposideros.

Venables (1943) states that evening emergence of pipistrelles does not usually occur at a temperature below $4^{\circ} \mathrm{C}$. When the roost at Braintree was visited on 25th May 1967, following a report that the bats had been seen emerging the evening before, the temperature at dusk was $9^{\circ} \mathrm{C}$. The bats did not emerge but remained silent and inactive. When these bats were caught at dusk 15 days later, the temperature was $12.5^{\circ} \mathrm{C}$ and much squeaking and activity could be heard through the thin walls of the roost before they emerged.

If environmental conditions at the times of emergence are unfavourable and a state of inactivity such as that observed on the visit to Braintree on 25th May is maintained, the bats will not be able to feed. The results of these experiments indicate that under such adverse conditions in the natural environment bats will become torpid and their pregnancies will be extended, as was suggested for Corynorhinus rafinesquei in California by Pearson, Koford \& Pearson (1952). These authors observed a marked variability in the gestation period (56 to 100 days) of this species in different localities and different years. A similar effect of environmental temperature was suggested by Kolb (1950) who related a 3-week delay compared with the previous year in the appearance of the first young of a nursery colony of Rhinolophus hipposideros to the occurrence of a 3-week cold spell in May. Eisentraut (1937) concluded that pregnant $M$. myotis, in spite of the more active metabolism associated with pregnancy, are still capable of 'day-sleep-lethargy', which in a low enough environmental temperature can become a state of hibernation lasting for several days. Consequently, animals which he kept singly in rooms at different temperatures, but with available food, contained foetuses of different size when killed, indicating that the rate of foetal development is not stopped but merely slowed.

Holm (1967) in his review of prolonged gestation finds that, of the various factors involved, environmental influences have been little studied. In hamsters, however, hypothermia induced by administration of drugs and exposure to cold, caused an extension of gestation by 3 days (Czajkowski, 1958).

In the current experiments, the slowing down of gestation resulted not only from the induction of torpor but also from the associated lack of food intake. The fact that the experimental procedure does not in itself adversely affect the successful completion of pregnancy and parturition is indicated by the high proportion of successful births in Exp. 1. The more extensive handling that took place to diagnose pregnancy in the Braintree animals was thought to have adversely affected the survival of foetuses and their mothers in Exp. 2.

Thus it would appear that the concept of a fixed period of gestation may be invalid in these heterothermic animals which can spend varying amounts of time during pregnancy in torpor. Whether the control of environmental temperature during pregnancy will allow a constant gestation period to be defined is in process of examination. 


\section{ACKNOWLEDGMENTS}

I am grateful to Dr I. W. Rowlands for his help and encouragement in this work and in the preparation of this paper, to Dr L. G. Goodwin for making available the X-ray facilities of the Nuffield Institute of Comparative Medicine, to Miss P. Verity who took the X-rays and Dr G. du Boulay who interpreted them. Mr D. A. Preece of Rothamsted Experimental Station kindly undertook the statistical analysis. My colleague Miss D. Kleiman helped in the examination of the bats for parturition and Miss P. Notcutt assisted in catching them. This work was supported by the World Health Organization.

\section{REFERENCES}

Aubert, A. (1963) Observation sur l'accouplement des chiroptères. Acta theriol. 6, 300.

Courrier, R. (1922) Le cycle génital chez certains mammifères hibernants. C. r. Séanc. Soc. Biol. 87, 1365.

CzajkowsKI, W. (1958) The effect of hypothermia on the duration of pregnancy in the golden hamster. Folia biol. Kraków. 6, 195.

Deanesly, R. \& Warwick, T. (1939) Observation on pregnancy in the common bat (Pipistrellus pipistrellus). Proc. zool. Soc. Lond. A, 109, 57.

Ersentraut, M. (1937) Die wirkung niedriger Temperaturen auf die Embryonalentwicklung bei Fledermäusen. Biol. Z Zbl. 57, 59.

Gilbert, O. \& Stebbings, R. (1958) Winter roosts of bats in West Suffolk. Proc. zool. Soc. Lond. 131, 329.

Guthrie, M. J. \& JEFFERs, K. R. (1938) The ovaries of the bat Myotis lucifugus lucifugus after injection of hypophyseal extract. Anat. Rec. 72, 11.

Hock, R. J. (1951) The metabolic rates and body temperatures of bats. Biol. Bull. mar. biol. Lab., Woods Hole, 101, 289.

HoLm, L. W. (1967) Prolonged pregnancy. Adv. vet. Sci. 11, 159.

Kleiman, Devra G. (1969) Maternal care, growth rate, and development in the noctule (Nyctalus noctula), pipistrella (Pipistrellus pipistrellus), and serotine (Eptesicus septinus) bats. F. Zool., Lond. $157,187$.

Korв, A. (1950) Beitrage sur Biologie einheimischer Fledermäuse. Zool. Fb. Abt. Syst. Ökol. Georgr. Tiere, $78,547$.

Moffat, C. B. (1922) The habits of the long-eared bat. Ir. Nat. 31, 105.

Pearson, O. P., Koford, M. R. \& Pearson, A. K. (1952) Reproduction of the lump-nosed bat (Corynorhinus rafinesquei) in California. F. Mammal, 33, 273.

Ransome, R. D. (1968) The distribution of the Greater Horseshoe bat, Rhinolophus ferrum-equinum, during hibernation, in relation to environmental factors. F. Zool., Lond. 154, 77.

Sluiter, J. W. (1954) Sexual maturity in bats of the genus Myotis. II. Females of M. mystacinus and supplementary data on female $M$. myotis and $M$. emarginatus. Proc. $K$. ned. Akad. Wet. C, 57, 696.

Sluiter, J. S. \& Bels, L. (1951) Follicular growth and spontaneous ovulation in captive bats during the hibernation period. Proc. K. ned. Akad. Wet. C, 54, 585.

Sluiter, J. W. \& Bouman, M. (1951) Sexual maturity in bats of the genus Myotis. I. Size and histology of the reproductive organs during hibernation in connection with age and wear of the teeth in female Myotis myotis and Myotis emarginatus. Proc. K. ned. Akad. Wet. C, 54, 594.

Stebings, R. E. (1966) A population of bats of the genus Plecotus. F. Zool., Lond. 150, 53.

Strelkov, P. (1962) The peculiarities of reproduction in bats (Vespertilionidae) near the northern border of their distribution. Int. Symp. Meth. mammal. Invest. Brno, 1960, 306 Praha.

Venables, L. S. V. (1943) Observations at a pipistrelle bat roost. F. Anim. Ecol. $12,19$.

Wimsatr, W. A. (1944a) Further studies on the survival of spermatozoa in the female reproductive tract of the bat. Anat. Rec. 88, 193.

Wimsatt, W. A. (1944b) Growth of the ovarian follicle and ovulation in Myotis lucifugus. Am. F. Anat. 74, 129.

WIMsatT, W. A. (1960) Some problems of reproduction in relation to hibernation in bats. Bull. Mus. comp. Zool. Harv. 124, 249. 